Article

\title{
New Water-Soluble Condensed Heterocyclic Compounds with Antimicrobial Activity Based on Annulation Reactions of 8-Quinolinesulfenyl Halides with Natural Products and Alkenes
}

\author{
Vladimir A. Potapov ${ }^{1, *(\mathbb{D})}$, Roman S. Ishigeev ${ }^{1} \mathbb{D}$, Lyudmila A. Belovezhets ${ }^{1}$, Irina V. Shkurchenko ${ }^{1,2}$ \\ and Svetlana V. Amosova ${ }^{1}$ D
}

1 A. E. Favorsky Irkutsk Institute of Chemistry, Siberian Division of The Russian Academy of Sciences, 1 Favorsky Str., 664033 Irkutsk, Russia; ishigeev@irioch.irk.ru (R.S.I.); belovezhets@irioch.irk.ru (L.A.B.); mindofchem@gmail.com (I.V.S.); amosova@irioch.irk.ru (S.V.A.)

2 Pedagogical Institute, Irkutsk State University, 6 Nizhnyaya Naberezhnaya Str., 664003 Irkutsk, Russia

* Correspondence: v_a_potapov@irioch.irk.ru

check for

updates

Citation: Potapov, V.A.; Ishigeev, R.S.; Belovezhets, L.A.; Shkurchenko, I.V.; Amosova, S.V. New WaterSoluble Condensed Heterocyclic Compounds with Antimicrobial Activity Based on Annulation Reactions of 8-Quinolinesulfenyl Halides with Natural Products and Alkenes. Appl. Sci. 2021, 11, 8532. https://doi.org/10.3390/app11188532

Academic Editors: Lucjusz Zaprutko and Anna Pawelczyk

Received: 19 August 2021

Accepted: 10 September 2021

Published: 14 September 2021

Publisher's Note: MDPI stays neutral with regard to jurisdictional claims in published maps and institutional affiliations.

Copyright: (c) 2021 by the authors. Licensee MDPI, Basel, Switzerland. This article is an open access article distributed under the terms and conditions of the Creative Commons Attribution (CC BY) license (https:/ / creativecommons.org/licenses/by/ $4.0 /)$.

\begin{abstract}
The annulation reactions of 8-quinolinesulfenyl halides with natural products and alkenes affording new water-soluble [1,4]thiazino[2,3,4-ij]quinolin-4-ium derivatives in high or quantitative yields are developed in this study. The reactions with styrene derivatives and terminal alkenes including allyl arenes proceed in a regioselective manner but with the opposite regiochemistry. The reactions with terminal alkenes including allyl arenes occur in an anti-Markovnikov fashion (regarding addition of the 8-quinolinesulfenyl electrophile to the double bond) to give 2-organyl-2 $\mathrm{H}, 3 \mathrm{H}$-[1,4]thiazino[2,3,4$i j$ ]quinolin-4-ium halides, while the reactions with styrene derivatives proceed in a Markovnikov fashion, leading to 3-substituted condensed heterocyclic compounds. In general, styrene derivatives demonstrate higher reactivity in the annulation reactions compared to the terminal alkenes. Antimicrobial activity of novel water-soluble compounds against Enterococcus durans, Bacillus subtilis and Escherichia coli are evaluated. The compounds with high antimicrobial activity are found. The annulation products of the reactions of 8-quinolinesulfenyl halides with $1 H$-indene, eugenol, methyl eugenol and 1-heptene, are superior in their activity compared to the antibiotic gentamicin.
\end{abstract}

Keywords: annulation reactions; [1,4]thiazino[2,3,4-ij]quinolin-4-ium derivatives; 8-quinolinesulfenyl chloride; heterocycles; natural products; alkenes

\section{Introduction}

The quinoline skeleton occurs in many natural products, including alkaloids. Some containing the quinoline ring natural products have been used as lead molecules for the development of novel biologically active compounds and drugs [1-5]. Many modern drugs have been designed based on the quinoline scaffold. The quinoline scaffold has often been used for the design and synthesis of various synthetic compounds with pharmacological properties [1-8].

The quinoline ring is a structural part of many biologically active compounds. Quinoline derivatives exhibit a variety of biological activities including antibacterial, antivirus, anticancer, antifungal, antimalarial, cardiovascular, anticonvulsant, analgesic, antimycobacterial, anti-inflammatory, antihelminthic, antiprotozoal and antioxidant properties [1-10]. Such antimalarial drugs as chloroquine, hydroxychloroquine, amodiaquine, and primaquine have been developed based on the quinoline scaffold [1-8].

Fluoroquinolone drugs are some of the most commonly used antibiotics in modern pharmacotherapy. These drugs are broad-spectrum bacteriocidals, which exhibit high activity against both Gram-negative and Gram-positive bacteria [1-7]. A number of fluoroquinolone antibiotics have a tricyclic core structure (pazufloxacin, rufloxacin, nadifloxacin), 
in which the quinoline ring is condensed with six-membered cycles (2,3-dihydro-1,4thiazine, 2,3-dihydro-1,4-oxazine, Figure 1).

A variety of biologically active compounds are based on scaffolds in the form of a combination of nitrogen and sulfur heterocycles [11-20]. Pazufloxacin, rufloxacin and nadifloxacin antibiotics have the quinoline core structure condensed with six-membered heterocycles (Figure 1) [17-19]. The well-known antibiotics penicillin and cephalosporin are examples of drugs containing fused nitrogen and sulfur heterocycles.

The [1,4]thiazino[2,3,4-ij]quinolin-4-ium scaffold can be considered as being a result of annulation of the quinoline core structure with the thiazine heterocycle. The [1,4]thiazino[2,3,4-ij]quinolin-4-ium derivatives exhibit a broad spectrum of biological activities [18-23], including anticancer [21], antibacterial [22] and anti-tuberculosis [23] properties. The commonly used fluoroquinolone antibiotic rufloxacin belongs structurally to this class of compounds (Figure 1).<smiles>CC1COc2c(C3(N)CC3)c(F)cc3c(=O)c(C(=O)O)cn1c23</smiles>

Pazufloxacin<smiles>CN1CCN(c2c(F)cc3c(=O)c(C(=O)O)cn4c3c2SCC4)CC1</smiles>

Rufloxacin<smiles>CC1CCc2c(N3CCC(O)CC3)c(F)cc3c(=O)c(C(=O)O)cn1c23</smiles>

Nadifloxacin<smiles>CC1CSc2c(Br)c(F)cc3cc(C(=O)O)c(=O)n1c23</smiles>

Antibacterial activity<smiles>CN1CCN(c2c(F)cc3c(=O)c(/C=N/NC(=O)c4ccncc4)cn4c3c2SCC4)CC1</smiles>

Anti-tuberculosis activity<smiles>CC1CSc2c(N3CCC(C4(N)CC4)C3)c(F)cc3cc(C(=O)O)c(=O)n1c23</smiles>

Antibacterial activity

Figure 1. Known biologically active compounds structurally related to the $2 H, 3 H$-[1,4]thiazino[2,3,4-ij]quinolin-4-ium scaffold, which have the quinoline ring condensed with six-membered cycles (fluoroquinolone antibiotics [17-19], compounds with antibacterial [22] and anti-tuberculosis [23] activity).

In the last decade, we have developed efficient regioselective approaches to novel heterocyclic and condensed organochalcogen compounds by means of cyclization and annulation reactions based on chalcogen-containing reagents and unsaturated compounds [24-33]. Recently, we carried out the annulation reactions of 8-quinolinesulfenyl halides with vinyl heteroatom compounds and cycloalkenes to obtain novel [1,4]thiazino[2,3,4-ij]quinolin4 -ium derivatives in high yields [32,33]. For example, the annulation reactions with divinyl sulfide and divinyl selenide proceeded with the addition of the sulfur atom of 8-quinolinesulfenyl electrophile at the $\beta$-position of the vinylchalcogenyl group (the Markovnikov direction), affording 3-(vinylsulfanyl)- and 3-(vinylselanyl)-2 $\mathrm{H}, 3 \mathrm{H}$-thiazino quinolin-4-ium chlorides in $94 \%$ and $50 \%$ yields, respectively. However, in the case of tetravinyl silane, the attachment of the sulfur atom occurred at the $\alpha$-carbon atom of the vinylsilyl group (the anti-Markovnikov direction), leading to 2-(trivinylsilyl)-2 $\mathrm{H}, 3 \mathrm{H}$ [1,4]thiazino[2,3,4-ij]quinolin-4-ium chloride in a 98\% yield [32].

The reactions of 8-quinolinesulfenyl halides (chloride and bromide) with cycloalkenes (cyclopentene, cyclohexene, and cyclooctene), depending on the nature of the halogen and 
the reaction conditions, gave products of electrophilic addition or annulation products in high yields [33]. The reactions of 8-quinolinesulfenyl chloride with cycloalkenes afforded 8[(2-chlorocycloalkyl)sulfanyl]quinolines in quantitative yields, while condensed tetracyclic compounds were synthesized in $90-100 \%$ yields from 8-quinolinesulfenyl bromide and cycloalkenes. Thus, the reaction of 8-quinolinesulfenyl chloride with cyclopentene at room temperature in methylene chloride gave 8-[(2-chlorocyclopentyl)sulfanyl]quinoline in a quantitative yield, whereas condensed tetracyclic compound, 8,9,10,10a-tetrahydro7aH-cyclopenta[5,6][1,4]thiazino[2,3,4-ij]quinolin-11-ium bromide (1), was obtained in a $98 \%$ yield by the annulation reaction of 8-quinolinesulfenyl bromide with cyclopentene in chloroform under reflux (Scheme 1) [33].<smiles>CC1CCCC1Sc1cccc2cccnc12</smiles>

$\mathrm{X}=\mathrm{Cl}, \mathrm{Br}$

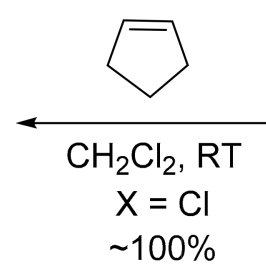

$\sim 100 \%$<smiles>[X]c1cccc2cccnc12</smiles>

X

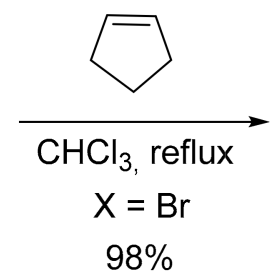

$98 \%$<smiles>Br[N+]1c2cccc3cccc(c23)SC2CCCC21</smiles>

1

Scheme 1. The annulation reactions of 8-quinolinesulfenyl chloride and bromide with cyclopentene.

Although some synthetic methods for the preparation of $[1,4]$ thiazino[2,3,4-ij] quinolin-4-ium derivatives have been developed [32-40], the annulation reactions of 8quinolinesulfenyl halides with natural products such as eugenol, isoeugenol, methyleugenol, anethole as well as with $1 H$-indene, styrene derivatives (4-methylstyrene and $\alpha$-methylstyrene) and simple alkenes (1-hexene and 1-heptene) have not been described in the literature.

The development of efficient selective methods for the preparation of new [1,4]thiazino quinolin-4-ium derivatives with promising biological activity is an urgent task. The aim of this research is the development of the regioselective synthesis of new derivatives of [1,4]thiazino[2,3,4-ij]quinolin-4-ium based on annulation reactions of 8-quinolinesulfenyl halides with natural products (eugenol, isoeugenol, methyleugenol, trans-anethole) as well as with 1-hexene, 1-heptene, $1 \mathrm{H}$-indene and styrene derivatives (4-methylstyrene and $\alpha$-methylstyrene) and the evaluation of their antimicrobial activity.

\section{Results and Discussion}

The starting compounds, 8-quinolinesulfenyl chloride 3 and bromide 4 , were generated in situ from di(8-quinolinyl) disulfide (2) in methylene chloride or chloroform and used without isolation in further reactions with alkenes and natural products (eugenol derivatives, trans-anethole) (Scheme 2).<smiles>c1cnc2c(SSc3cccc4cccnc34)cccc2c1</smiles>

2

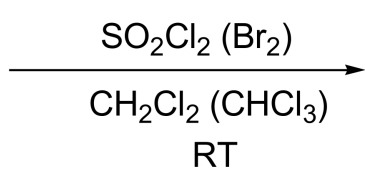

RT
2<smiles>[X]c1cccc2cccnc12</smiles>

3,4

$$
\mathrm{X}=\mathrm{Cl}(3) ; \mathrm{Br}(4)
$$

Scheme 2. The generation of 8-quinolinesulfenyl chloride 3 and bromide 4 from di(8-quinolinyl) disulfide 2 by the action of sulfuryl chloride or bromine. 
Taking into account the known data on the reactions of 8-quinolinesulfenyl halides with cycloalkenes [33], which produced electrophilic addition products of sulfenyl chloride 3 and annulation products in the case of sulfenyl bromide 4 (Scheme 1), it could be assumed that the reactions of 8-quinolinesulfenyl halides with 1-alkenes would proceed similarly. However, the reactions of sulfenyl chloride 3 with 1-alkenes gave a complex mixture of compounds including electrophilic addition products under the same conditions as indicated in Scheme 1. Nevertheless, the reactions of sulfenyl bromide 4 with 1-alkenes at room temperature in methylene chloride led to annulation products 5 and 6 in $85 \%$ and $81 \%$ yields, respectively (Scheme 3 ).<smiles></smiles>

5

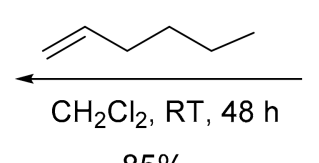

$85 \%$<smiles>Brc1cccc2cccnc12</smiles>

4

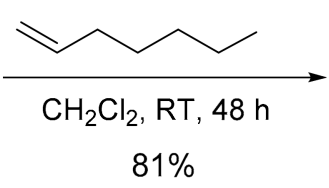

$81 \%$

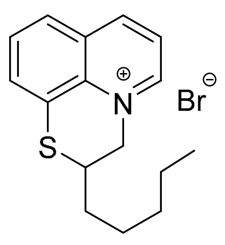

6

Scheme 3. Synthesis of 2-butyl- and 2-pentyl-2H,3H-[1,4]thiazino[2,3,4-ij]quinolin-4-ium bromides 5 and 6 from sulfenyl bromide 4 and 1-alkenes.

Compounds 5 and 6 are water-soluble light-yellow powders with a melting point of about $120^{\circ} \mathrm{C}$.

The naturally occurring products eugenol (4-allyl-2-methoxyphenol) and isoeugenol (2methoxy-4-(1-propenyl)phenol) were involved in the annulation reactions with 8 -quinolinesulfenyl chloride 3 . The reaction of sulfenyl chloride 3 with isoeugenol smoothly proceeded at room temperature in chloroform, giving compound 7 in a $90 \%$ yield (Scheme 4 ).<smiles></smiles>

7<smiles>C/C=C/c1ccc(O)c(OC)c1</smiles>

3

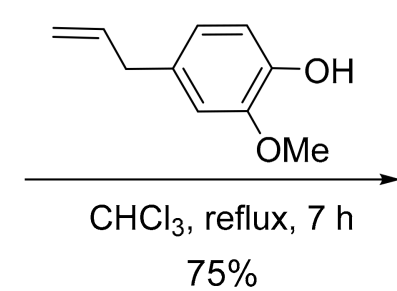

$75 \%$<smiles></smiles>

8

Scheme 4. Synthesis of compounds 7 and 8 by the annulation reactions of sulfenyl chloride 3 with isoeugenol and eugenol.

The reaction of sulfenyl chloride 3 with eugenol under the same conditions as the synthesis of compound 7 was very sluggish ( $40 \%$ yield of the annulation product). However, carrying out the reaction of sulfenyl chloride 3 with eugenol under reflux in chloroform for $7 \mathrm{~h}$ allowed us to obtain annulation product 8 in a 75\% yield (Scheme 4 ).

The reaction of sulfenyl chloride 3 with eugenol includes electrophilic addition of the sulfur atom of sulfenyl electrophile to the $\alpha$-carbon atom of the vinyl group (the antiMarkovnikov direction), while the opposite regiochemistry is observed in the annulation reaction of sulfenyl chloride 3 with isoeugenol.

Another naturally occurring compound, trans-anethole (1-methoxy-4-(E-1-propenyl) benzene), appears to be very reactive in annulation reactions. The reaction of sulfenyl chloride 3 with trans-anethole was carried out at room temperature in methylene chloride, affording quinolinium chloride 9 in a quantitative yield (Scheme 5). 
<smiles>COc1ccc(C2c3c4ccc[n+]3C(=CC=C4)SC2C)cc1</smiles>

9

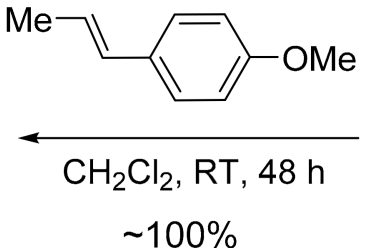

$\sim 100 \%$<smiles>ClSc1cccc2cccnc12</smiles>

3

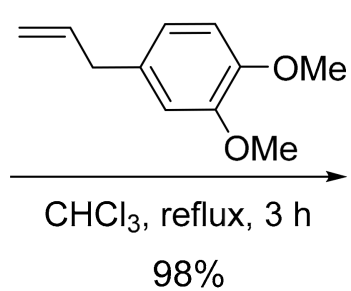

$98 \%$

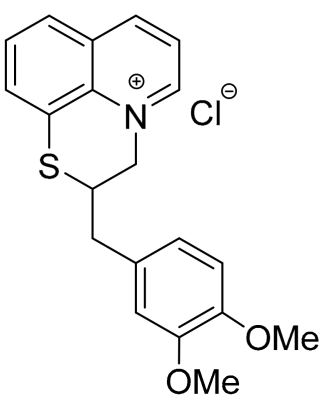

10

Scheme 5. Synthesis of compounds $\mathbf{9}$ and $\mathbf{1 0}$ by the annulation reactions of sulfenyl chloride $\mathbf{3}$ with trans-anethole and methyl eugenol.

The reaction of sulfenyl chloride 3 with methyl eugenol (4-allyl-1,2-dimethoxybenzene) seems to proceed more slowly than with eugenol. Under the same conditions as the synthesis of product $\mathbf{9}$, the reaction of sulfenyl chloride 3 with methyl eugenol afforded the annulation product in a 57\% yield. However, after refluxing the mixture of sulfenyl chloride 3 with methyl eugenol in chloroform for $3 \mathrm{~h}$, annulation product $\mathbf{1 0}$ was obtained in a $98 \%$ yield (Scheme 5 ).

The double bond in trans-anethole and isoeugenol occurs in conjugation with the benzene ring, and these compounds demonstrate higher activity in the annulation reactions compared to eugenol and methyl eugenol bearing the allyl fragment without conjugation of the double bond.

Such substrates as styrene, 4-methylstyrene and $\alpha$-methylstyrene and $1 H$-indene also have the double bond, which is in conjugation with the benzene ring. We assumed that these substrates may be active in the annulation and carried out the reactions of sulfenyl chloride 3 with them.

The reactions of quinoline sulfenyl chloride 3 with styrene proceeded smoothly in methylene chloride at room temperature for $24 \mathrm{~h}$ to give quinolinium chloride $\mathbf{1 1}$ in a $97 \%$ yield (Scheme 6).<smiles></smiles>

11

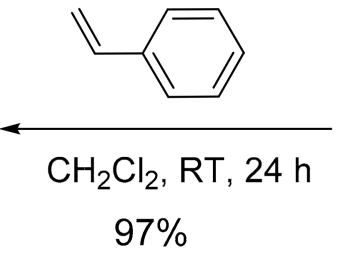

$97 \%$<smiles>Cl[Si]c1cccc2cccnc12</smiles>

3

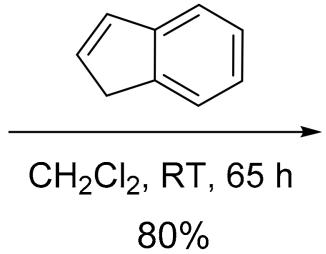

$80 \%$

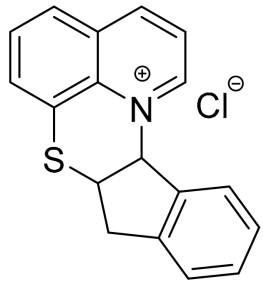

12

Scheme 6. Synthesis of compounds $\mathbf{1 1}$ and $\mathbf{1 2}$ by the annulation reactions of sulfenyl chloride 3 with styrene and $1 H$-indene.

Under the same conditions, the reactions of sulfenyl chloride 3 with $1 H$-indene afforded the condensed five-membered product in only a $43 \%$ yield. Refluxing the reaction mixture resulted in the formation of a small amount of by-product along with the target compound. However, when the reaction time was increased to $65 \mathrm{~h}$ at room temperature, pure annulation product 12 was obtained in an $80 \%$ yield (Scheme 6).

The reaction of sulfenyl chloride 3 with 4-methylstyrene was carried out at room temperature for $24 \mathrm{~h}$ in methylene chloride affording compound $\mathbf{1 3}$ in quantitative yield (Scheme 7). Under the same conditions as the synthesis of product 13, the reaction of sulfenyl chloride 3 with $\alpha$-methylstyrene gave annulation product 14 in an $87 \%$ yield (Scheme 7). 
<smiles></smiles>

13

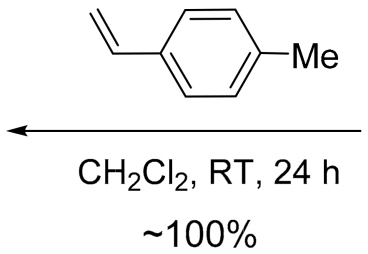

$\sim 100 \%$<smiles>[Si]c1cccc2cccnc12</smiles>

3

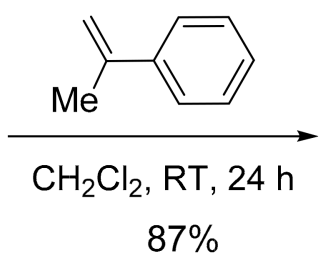

$87 \%$<smiles></smiles>

14

Scheme 7. Synthesis of compounds $\mathbf{1 3}$ and $\mathbf{1 4}$ by the annulation reactions of sulfenyl chloride 3 with 4 -methylstyrene and $\alpha$-methylstyrene.

The reaction of sulfenyl chloride 3 with $\alpha$-methylstyrene seems to proceed more slowly than with 4-methylstyrene and styrene. The methyl substituent at position 4 of the benzene ring has little influence on the yield of the product, and compounds $\mathbf{1 1}$ and $\mathbf{1 3}$ (derived from both styrene and 4-methylstyrene) were obtained in $97 \%$ and quantitative yields, while the introduction of the methyl substituent to the $\alpha$-position of the double bond affects on the annulation reaction and slightly decreases the the annulation product yield to $87 \%$ under the same conditions.

All the studied substrates can be schematically divided into two groups: terminal alkenes including allyl arenes and styrene derivatives, which contain the double bond in conjugation with the benzene ring. In general, the latter group of compounds demonstrates the higher activity in the annulation reactions compared to the terminal alkenes (Scheme 8).

$$
\lceil
$$

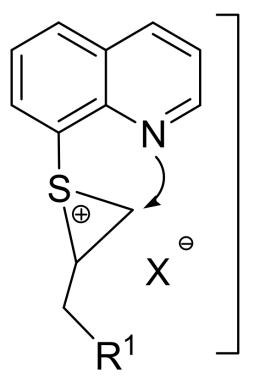

A<smiles>[R]CC1C[n+]2cccc3cccc(c32)S1</smiles>

$5,6,8,10$<smiles>[R]C/C=C\C</smiles><smiles>[X]c1cccc2cccnc12</smiles><smiles>[R]C=C([R])[Al]</smiles>

3,4<smiles>[R]C(Sc1cccc2cccnc12)C([R])(Br)Br</smiles>

B<smiles></smiles>

$7,9,11-14$

$\mathrm{R}^{1}=\mathrm{C}_{4} \mathrm{H}_{9}(\mathbf{5}), \mathrm{C}_{5} \mathrm{H}_{11}(\mathbf{6}), 4-\mathrm{HO}(3-\mathrm{MeO}) \mathrm{C}_{6} \mathrm{H}_{3}(\mathbf{8}), 3,4-(\mathrm{MeO}){ }_{2} \mathrm{C}_{6} \mathrm{H}_{3}(\mathbf{1 0})$,

$\mathrm{R}^{2}=\mathrm{Me}, \mathrm{R}^{3}=\mathrm{H}, \mathrm{Ar}=4-\mathrm{HO}(3-\mathrm{MeO}) \mathrm{C}_{6} \mathrm{H}_{3}(7) ; \mathrm{R}^{2}=\mathrm{Me}, \mathrm{R}^{3}=\mathrm{H}, \mathrm{Ar}=4-(\mathrm{MeO}) \mathrm{C}_{6} \mathrm{H}_{4}(9) ;$

$\mathrm{R}^{2}=\mathrm{H}, \mathrm{R}^{3}=\mathrm{H}, \mathrm{Ar}=\mathrm{C}_{6} \mathrm{H}_{5}(11) ; \mathrm{R}^{2} \mathrm{CH}=\mathrm{C}\left(\mathrm{R}^{3}\right) \mathrm{Ar}=1 \mathrm{H}$-indene (12);

$\mathrm{R}^{2}=\mathrm{H}, \mathrm{R}^{3}=\mathrm{H}, \mathrm{Ar}=4-\mathrm{MeC}_{6} \mathrm{H}_{4}(13), \mathrm{R}^{2}=\mathrm{H}, \mathrm{R}^{3}=\mathrm{Me}, \mathrm{Ar}=\mathrm{C}_{6} \mathrm{H}_{5}(14)$

Scheme 8. Directions of the reactions of sulfenyl chloride 3 and bromide 4 with natural products and alkenes. 
The annulation reactions with the terminal alkenes, whose double bond is not in conjugation with the benzene ring, proceed with the attachment of the sulfur atom of sulfenyl halides 3, 4 at the $\alpha$-position of the double bond (the anti-Markovnikov direction). In the case of styrene derivatives, the addition of the sulfur atom occurs at the terminal carbon atom of the double bond (the Markovnikov direction). Possible intermediates A and $\mathbf{B}$, which correspond to two directions of these reactions, can be considered for the explanation of these trends (Scheme 8).

We assume that the reactions with terminal alkenes proceed via three-membered thiiranium intermediates A. It is known that the electrophilic addition reactions of sulfenyl chlorides [41-54] with linear 1-alkene mainly give anti-Markovnikov products [41-43], and thiiranium cations are regarded as intermediates of these reactions [42-45]). Nucleophilic attack of the nitrogen atom of the quinoline ring occurs at the unsubstituted carbon atom of thiiranium intermediates A due to the steric factor, which determines the anti-Markovnikov direction of the reactions (Scheme 8).

It is assumed that linear carbocations $\mathbf{B}$ are involved as intermediates in the reactions with styrene derivatives. In this case, linear carbocations $\mathbf{B}$ are energetically favorable due to their stabilization by the benzene ring that provides the Markovnikov direction of the reactions (Scheme 8). It is known that electrophilic addition of sulfenyl chlorides to styrene leads to Markovnikov products [52,53].

The antibacterial activity of the synthesized compounds was evaluated. The minimal inhibitory concentration (MIC) was determined using the broth standard microdilution method [55].

The obtained results are presented in Table 1 . Compounds $\mathbf{1 , 5 - 1 4}$ were tested in vitro for antimicrobial activity against strains of the Gram-positive bacteria Bacillus subtilis B-406 and Enterococcus durans B-603 (which are similar in properties and taxonomic affiliation to bacteria Staphylococcus aureus) and the Gram-negative bacteria Escherichia coli B-1238 (the bacterial strains were taken from the All-Russian Collection of Microorganisms).

Table 1. The evaluation of antibacterial activity of compounds $\mathbf{1 , 5 - 1 4}$

Compound Minimum Inhibitory Concentration $(\mu \mathrm{g} / \mathrm{mL})$


Table 1. Cont.

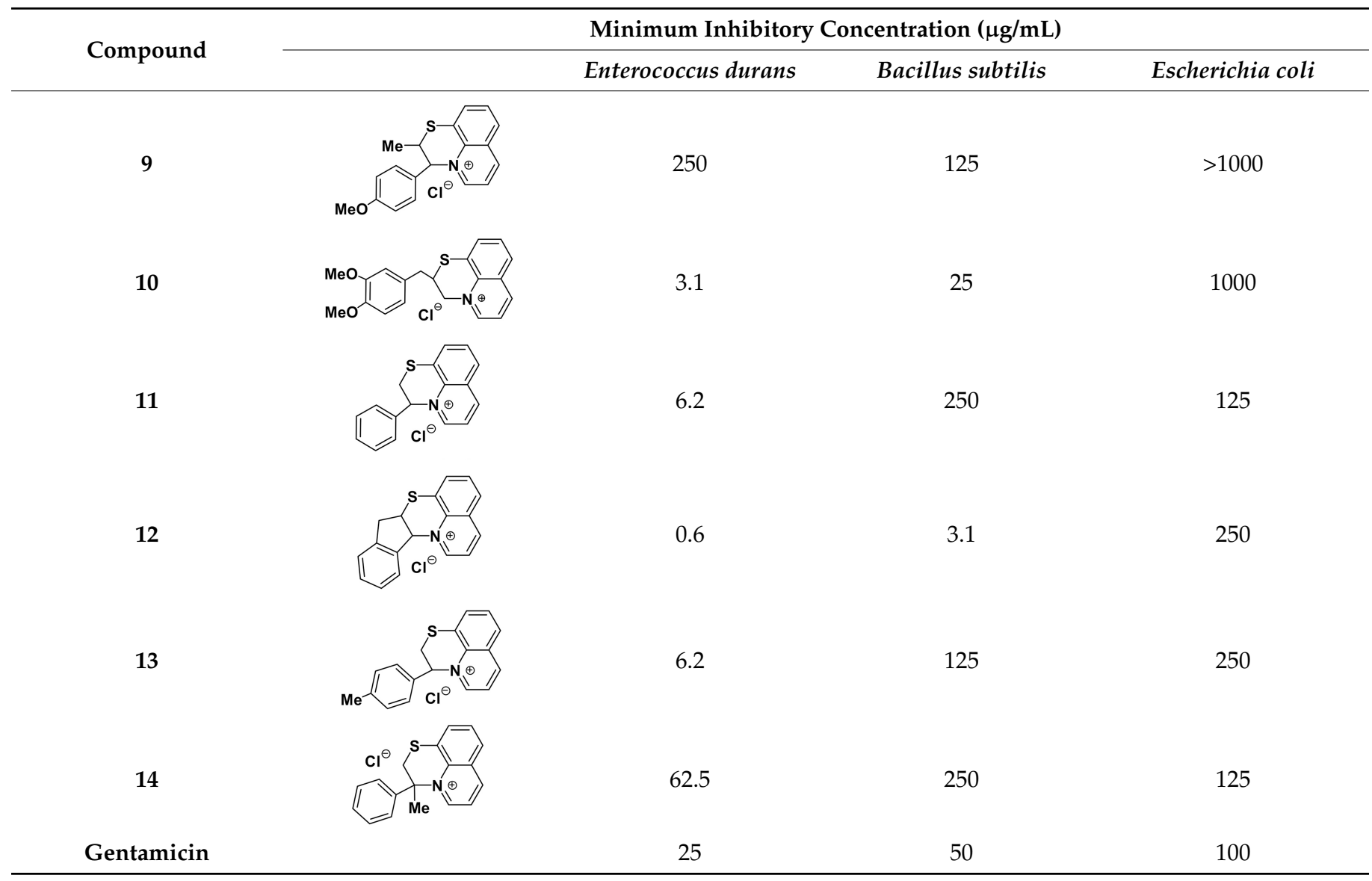

As can be seen from the presented data (Table 1), compound $\mathbf{1}$ is active against Enterococcus durans, but has low activity against other microorganisms. Compounds $\mathbf{5}$ and 6 differ only by one group, $\mathrm{CH}_{2}$, but the activity of these compounds varies considerably. Compound $\mathbf{5}$ with a shorter carbon chain shows low activity, while compound $\mathbf{6}$ is superior to antibiotic gentamicin against both the Gram-positive Enterococcus durans and the Gramnegative Escherichia coli (Table 1).

The obtained results were compared with the activity of standard aminoglycoside antibiotic gentamicin, the minimal inhibitory concentrations of which are 25,50 and $100 \mathrm{\mu g} / \mathrm{mL}$ against Enterococcus durans, Bacillus subtilis and Escherichia coli, respectively.

Having the same molecular formula, products $\mathbf{7}$ and $\mathbf{8}$ are isomeric compounds obtained by the reactions of sulfenyl chloride 3 with isoeugenol and eugenol, respectively. These compounds differ significantly (by about 10 times) in activity (Table 1). The eugenolderived product 8, as well as that obtained from methyl eugenol, compound 10, are highly active against bacteria Enterococcus durans and Bacillus subtilis and are superior in their activity compared the antibiotic gentamicin against these microorganisms.

The structurally related compounds $\mathbf{7}$ and $\mathbf{9}$ (obtained from methyl isoeugenol and trans-anethole), which formally differ in one hydroxyl group, show activity against Grampositive bacteria Enterococcus durans and Bacillus subtilis, but are inferior to gentamicin (Table 1).

Comparison of the structurally related compounds 11, 13 and 14 reveals the higher activity of products $\mathbf{1 1}$ and $\mathbf{1 3}$ (obtained from styrene and 4-methylstyrene), which are superior to the activity of gentamicin against bacteria Enterococcus durans. $\alpha$-methylstyrenederived product 14 shows lower activity (Table 1 ).

The highest level of activity was shown by product 12 (obtained from $1 H$-indene), which significantly exceeds the activity of gentamicin and all the obtained compounds 
against the bacteria Enterococcus durans and is more than 15 times higher than the activity of this antibiotic against Bacillus subtilis.

The structural assignments of synthesized compounds were made using ${ }^{1} \mathrm{H}$ - and ${ }^{13} \mathrm{C}$-NMR spectroscopy including $J$-modulation ${ }^{13} \mathrm{C}$-NMR experiments and confirmed by elemental analysis (see more in Supplementary Materials).

The groups $\mathrm{SCH}-\mathrm{CH}_{2} \mathrm{~N}^{+}, \mathrm{SCH}_{2}-\mathrm{CHN}^{+}$and $\mathrm{SCH}-\mathrm{CHN}^{+}$provide characteristic signals in the ${ }^{1} \mathrm{H}$ - and ${ }^{13} \mathrm{C}$-NMR spectra. Thus, the carbon atoms of these groups, bonded with one or two protons, reveal characteristic signals in the ${ }^{13} \mathrm{C}-\mathrm{NMR}$ spectra. For example, the $\mathrm{CH}_{2} \mathrm{~N}^{+}$group manifests itself at $\sim 62 \mathrm{ppm}$, while signals of the $\mathrm{CHN}^{+}$moiety are observed in the lowfield region of $\sim 69-75 \mathrm{ppm}$ in the ${ }^{13} \mathrm{C}$-NMR spectra of the obtained compounds. The regiochemistry of the products was determined based on the ${ }^{1} \mathrm{H}$ - and ${ }^{13} \mathrm{C}-\mathrm{NMR}$ spectra, taking into account the number of protons bonded with the carbon atoms of these groups.

\section{Experimental Section}

\subsection{General Information}

${ }^{1} \mathrm{H}(400.1 \mathrm{MHz})$ and ${ }^{13} \mathrm{C}(100.6 \mathrm{MHz}) \mathrm{NMR}$ spectra were recorded on a Bruker DPX400 spectrometer (Bruker BioSpin $\mathrm{GmbH}$, Rheinstetten, Germany) in a 2-5\% solution with $\mathrm{D}_{2} \mathrm{O}$ or DMSO- $d_{6} .{ }^{1} \mathrm{H}$ and ${ }^{13} \mathrm{C}$ chemical shifts $(\delta)$ are reported in parts per million (ppm), relative to tetramethylsilane (external) or to the residual solvent peaks of $\mathrm{D}_{2} \mathrm{O}(\delta=4.79)$ and DMSO- $d_{6}\left(\delta=2.50\right.$ and $39.52 \mathrm{ppm}$ for ${ }^{1} \mathrm{H}$ and ${ }^{13} \mathrm{C}$ NMR, respectively). Elemental analysis was performed on a Thermo Scientific FLASH 2000 Organic Elemental Analyzer (Thermo Fisher Scientific Inc., Milan, Italy). Melting points were determined on a Kofler HotStage Microscope PolyTherm A apparatus (Wagner \& Munz GmbH, München, Germany). Absolute solvents were used in the reactions.

\subsection{Synthesis of Products $\mathbf{5}$ and $\mathbf{6}$ from 1-Alkenes}

2-Butyl-2H,3H-[1,4]thiazino[2,3,4-ij]quinolin-4-ium bromide (5). A solution of bromine $(0.072 \mathrm{~g}, 0.45 \mathrm{mmol})$ in methylene chloride $(10 \mathrm{~mL})$ was added dropwise to a solution of di(8-quinolinyl) disulfide $(0.144 \mathrm{~g}, 0.45 \mathrm{mmol})$ in methylene chloride $(10 \mathrm{~mL})$, and the mixture was stirred for $10 \mathrm{~min}$ at room temperature. A solution of hexene-1 $(0.076 \mathrm{~g}$, $0.9 \mathrm{mmol})$ in methylene chloride $(10 \mathrm{~mL})$ was added dropwise. The reaction mixture was stirred for $48 \mathrm{~h}$ at room temperature and left overnight. The mixture was filtered, and the solvent was removed by rotary evaporator. The residue was washed with cold hexane and dried in vacuum, giving the product $(0.248 \mathrm{~g}, 85 \%$ yield $)$ in the form of a yellow powder, mp $220-221{ }^{\circ} \mathrm{C}$.

${ }^{1} \mathrm{H}-\mathrm{NMR}\left(400 \mathrm{MHz}, \mathrm{DMSO}-d_{6}\right): \delta 0.90\left(\mathrm{t}, J=7.3 \mathrm{~Hz}, 3 \mathrm{H}, \mathrm{CH}_{3}\right), 1.31-1.39\left(\mathrm{~m}, 2 \mathrm{H}, \mathrm{CH}_{2}\right)$, 1.47-1.54 (m, 2H, $\left.\mathrm{CH}_{2}\right), 1.61-1.68\left(\mathrm{~m}, 1 \mathrm{H}, \mathrm{CH}_{2}\right), 1.80-1.89\left(\mathrm{~m}, 1 \mathrm{H}, \mathrm{CH}_{2}\right), 3.94(\mathrm{~m}, 1 \mathrm{H}, \mathrm{SCH})$, $5.01\left(\mathrm{dd}, J=13.9,8.5 \mathrm{~Hz}, 1 \mathrm{H}, \mathrm{NCH}_{2}\right), 5.36\left(\mathrm{~d}, J=13.9 \mathrm{~Hz}, 1 \mathrm{H}, \mathrm{NCH}_{2}\right), 7.88-7.92(\mathrm{~m}, 1 \mathrm{H}$, $\left.\mathrm{H}_{\text {quino }}\right), 8.12-8.14\left(\mathrm{~m}, 1 \mathrm{H}, \mathrm{H}_{\text {quino }}\right), 8.18-8.22\left(\mathrm{~m}, 2 \mathrm{H}, \mathrm{H}_{\text {quino }}\right), 9.28-9.30\left(\mathrm{~m}, 1 \mathrm{H}, \mathrm{H}_{\text {quino }}\right)$, 9.39-9.41 (m, 1H, $\left.\mathrm{H}_{\text {quino }}\right)$.

${ }^{13} \mathrm{C}-\mathrm{NMR}\left(101 \mathrm{MHz}, \mathrm{DMSO}-d_{6}\right): \delta 13.75\left(\mathrm{CH}_{3}\right), 21.65\left(\mathrm{CH}_{2}\right), 28.03\left(\mathrm{CH}_{2}\right), 30.81\left(\mathrm{CH}_{2}\right)$, $36.21(\mathrm{SCH}), 62.05\left(\mathrm{NCH}_{2}\right), 122.25\left(\mathrm{C}_{\text {quino }}\right), 126.40\left(\mathrm{C}_{\text {quino }}\right), 126.87\left(\mathrm{C}_{\text {quino }}\right), 129.39\left(\mathrm{C}_{\text {quino }}\right)$, 130.59 ( $\left.\mathrm{C}_{\text {quino }}\right), 133.14$ ( $\left.\mathrm{C}_{\text {quino }}\right), 133.61$ ( $\left.\mathrm{C}_{\text {quino }}\right), 148.65$ ( $\left.\mathrm{C}_{\text {quino }}\right), 150.23$ ( $\left.\mathrm{C}_{\text {quino }}\right)$.

Anal. Calcd for $\mathrm{C}_{15} \mathrm{H}_{18}$ BrNS: C 55.56, H 5.59, $\mathrm{N}$ 4.32, Br 24.64, $\mathrm{S}$ 9.89. Found: C 55.69, H 5.96, N 4.44, Br 24.86, S 10.10 .

2-Pentyl-2H,3H-[1,4]thiazino[2,3,4-ij]quinolin-4-ium bromide (6). A solution of bromine $(0.130 \mathrm{~g}, 0.80 \mathrm{mmol})$ in methylene chloride $(10 \mathrm{~mL})$ was added dropwise to a solution of di(8-quinolinyl) disulfide $(0.261 \mathrm{~g}, 0.80 \mathrm{mmol})$ in methylene chloride $(10 \mathrm{~mL})$, and the mixture was stirred for $10 \mathrm{~min}$ at room temperature. A solution of heptene- $1(0.157 \mathrm{~g}$, $1.6 \mathrm{mmol})$ in methylene chloride $(10 \mathrm{~mL})$ was added dropwise. The reaction mixture was stirred for $48 \mathrm{~h}$ at room temperature and left overnight. The mixture was filtered, and the solvent was removed by rotary evaporator. The residue was washed with cold hexane and dried in vacuum, giving the product $(0.438 \mathrm{~g}, 81 \%$ yield $)$ in the form of a yellow powder, $\mathrm{mp} 219-220^{\circ} \mathrm{C}$. 
${ }^{1} \mathrm{H}-\mathrm{NMR}\left(400 \mathrm{MHz}, \mathrm{DMSO}-d_{6}\right): \delta 0.88\left(\mathrm{~s}, 3 \mathrm{H}, \mathrm{CH}_{3}\right), 1.30-1.32\left(\mathrm{~m}, 4 \mathrm{H}, \mathrm{CH}_{2}\right), 1.49-1.56$ (m, 2H, $\left.\mathrm{CH}_{2}\right), 1.58-1.65\left(\mathrm{~m}, 1 \mathrm{H}, \mathrm{CH}_{2}\right), 1.81-1.84\left(\mathrm{~m}, 1 \mathrm{H}, \mathrm{CH}_{2}\right), 3.94(\mathrm{~m}, 1 \mathrm{H}, \mathrm{SCH}), 5.01$ (dd, $\left.J=13.7,8.3 \mathrm{~Hz}, 1 \mathrm{H}, \mathrm{NCH}_{2}\right), 5.35\left(\mathrm{~d}, J=13.7 \mathrm{~Hz}, 1 \mathrm{H}, \mathrm{NCH}_{2}\right), 7.88-7.92\left(\mathrm{~m}, 1 \mathrm{H}, \mathrm{H}_{\text {quino }}\right)$, 8.12-8.13 (m, 1H, $\left.\mathrm{H}_{\text {quino }}\right), 8.18-8.22\left(\mathrm{~m}, 2 \mathrm{H}, \mathrm{H}_{\text {quino }}\right), 9.27-9.30\left(\mathrm{~m}, 1 \mathrm{H}, \mathrm{H}_{\text {quino }}\right), 9.39-9.41(\mathrm{~m}$, $\left.1 \mathrm{H}, \mathrm{H}_{\text {quino }}\right)$.

${ }^{13} \mathrm{C}-\mathrm{NMR}\left(101 \mathrm{MHz}, \mathrm{DMSO}-d_{6}\right): \delta 13.78\left(\mathrm{CH}_{3}\right), 21.82\left(\mathrm{CH}_{2}\right), 25.48\left(\mathrm{CH}_{2}\right), 30.60$ $\left(\mathrm{CH}_{2}\right), 31.01\left(\mathrm{CH}_{2}\right), 36.18(\mathrm{SCH}), 61.97\left(\mathrm{NCH}_{2}\right), 122.21\left(\mathrm{C}_{\text {quino }}\right), 126.36\left(\mathrm{C}_{\text {quino }}\right), 126.81$ $\left(\mathrm{C}_{\text {quino }}\right), 129.33\left(\mathrm{C}_{\text {quino }}\right), 130.54\left(\mathrm{C}_{\text {quino }}\right), 132.54\left(\mathrm{C}_{\text {quino }}\right), 133.10$ ( $\left.\mathrm{C}_{\text {quino }}\right), 148.60$ ( $\left.\mathrm{C}_{\text {quino }}\right)$, 150.19 ( $\left.\mathrm{C}_{\text {quino }}\right)$.

Anal. Calcd for $\mathrm{C}_{16} \mathrm{H}_{20}$ BrNS: C 56.80, $\mathrm{H}$ 5.96, N 4.14, Br 23.62, S 9.48. Found: C 57.02, H 6.11, N 4.24, Br 23.97, S 9.72.

\subsection{Synthesis of Compounds 7-10 from Natural Products}

3-(4-Hydroxy-3-methoxyphenyl)-2-methyl-2H,3H-[1,4]thiazino[2,3,4-ij]quinolin-4-ium chloride (7). A solution of sulfuryl chloride $(0.113 \mathrm{~g}, 0.83 \mathrm{mmol})$ in chloroform $(10 \mathrm{~mL})$ was added dropwise to a solution of di(8-quinolinyl) disulfide $(0.268 \mathrm{~g}, 0.83 \mathrm{mmol})$ in chloroform $(10 \mathrm{~mL})$, and the mixture was stirred for $10 \mathrm{~min}$ at room temperature. A solution of isoeugenol $(0.274 \mathrm{~g}, 1.6 \mathrm{mmol})$ in chloroform $(10 \mathrm{~mL})$ was added dropwise, and the reaction mixture was stirred for $45 \mathrm{~h}$ at room temperature and left overnight. The formed precipitate was filtered off, washed with hexane and dried in vacuum, giving the product $\left(0.54 \mathrm{~g}, 90 \%\right.$ yield) in the form of a yellow powder, mp $156-159{ }^{\circ} \mathrm{C}$.

${ }^{1} \mathrm{H}-\mathrm{NMR}\left(400 \mathrm{MHz}, \mathrm{DMSO}-d_{6}\right): \delta 1.40\left(\mathrm{~d}, J=7.0 \mathrm{~Hz}, 3 \mathrm{H}, \mathrm{CH}_{3}\right), 3.70\left(\mathrm{~s}, 3 \mathrm{H}, \mathrm{OCH}_{3}\right)$, $3.96(\mathrm{~m}, 1 \mathrm{H}, \mathrm{SCH}), 5.73(\mathrm{~m}, 1 \mathrm{H}, \mathrm{NCH}), 6.58(\mathrm{~m}, 1 \mathrm{H}, \mathrm{Ar}), 6.61(\mathrm{~m}, 1 \mathrm{H}, \mathrm{Ar}), 6.80$ (m, 1H, Ar), 7.94-7.98 (m, 1H, $\left.\mathrm{H}_{\text {quino }}\right), 8.14-8.16\left(\mathrm{~m}, 1 \mathrm{H}, \mathrm{H}_{\text {quino }}\right), 8.24-8.27\left(\mathrm{~m}, 1 \mathrm{H}, \mathrm{H}_{\text {quino }}\right), 8.32-8.34(\mathrm{~m}$, $\left.1 \mathrm{H}, \mathrm{H}_{\text {quino }}\right), 9.43-9.45\left(\mathrm{~m}, 1 \mathrm{H}, \mathrm{H}_{\text {quino }}\right), 9.48-9.50\left(\mathrm{~m}, 1 \mathrm{H}, \mathrm{H}_{\text {quino }}\right)$.

${ }^{13} \mathrm{C}-\mathrm{NMR}\left(101 \mathrm{MHz}, \mathrm{DMSO}-d_{6}\right): \delta 20.04\left(\mathrm{CH}_{3}\right), 37.46\left(\mathrm{SCH}_{2}\right), 55.74\left(\mathrm{OCH}_{3}\right), 73.69$ (NCH), 110.39, 115.40, 117.77, 122.94, 124.85, 127.68, 129.08, 129.70, 130.87, 132.96, 133.95, 147.17, 148.03, 150.25, 151.10.

Anal. Calcd for $\mathrm{C}_{19} \mathrm{H}_{18} \mathrm{NClO}_{2} \mathrm{~S}$ : C 63.41, H 5.04, N 3.89, Cl 9.85, S 8.91. Found: C 63.69, H 5.23, N 4.07, Cl 10.09, S 9.21.

2-[(4-Hydroxy-3-methoxyphenyl)methyl]-2H,3H-[1,4] thiazino[2,3,4-ij]quinolin-4-ium chloride (8). A solution of sulfuryl chloride $(0.167 \mathrm{~g}, 1.2 \mathrm{mmol})$ in chloroform $(10 \mathrm{~mL})$ was added dropwise to a solution of di(8-quinolinyl) disulfide $(0.396 \mathrm{~g}, 1.2 \mathrm{mmol})$ in chloroform $(10 \mathrm{~mL})$, and the mixture was stirred for $10 \mathrm{~min}$ at room temperature. A solution of eugenol $(0.394 \mathrm{~g}, 2.4 \mathrm{mmol})$ in chloroform $(10 \mathrm{~mL})$ was added dropwise. The reaction mixture was stirred for $1 \mathrm{~h}$ at room temperature and $7 \mathrm{~h}$ at reflux and left overnight. The formed precipitate was filtered off, washed with hexane and dried in vacuum, giving the product (0.648 $\mathrm{g}, 75 \%$ yield) in the form of a yellow powder, $\mathrm{mp} 195-197^{\circ} \mathrm{C}$.

${ }^{1} \mathrm{H}-\mathrm{NMR}\left(400 \mathrm{MHz}, \mathrm{D}_{2} \mathrm{O}\right): \delta 2.88-2.94\left(\mathrm{~m}, 1 \mathrm{H}, \mathrm{CH}_{2}\right), 3.02(\mathrm{dd}, J=14.2,6.0 \mathrm{~Hz}, 1 \mathrm{H}$, $\left.\mathrm{CH}_{2}\right), 3.68\left(\mathrm{~s}, 3 \mathrm{H}, \mathrm{CH}_{3}\right), 3.92-3.97(\mathrm{~m}, 1 \mathrm{H}, \mathrm{SCH}), 4.94\left(\mathrm{dd}, J=14.4,6.8 \mathrm{~Hz}, 1 \mathrm{H}, \mathrm{NCH}_{2}\right), 5.21$ $\left(\mathrm{dd}, J=14.4,2.4 \mathrm{~Hz}, 1 \mathrm{H}, \mathrm{NCH}_{2}\right), 6.48-6.53(\mathrm{~m}, 2 \mathrm{H}, \mathrm{Ar}), 6.68(\mathrm{~s}, 1 \mathrm{H}, \mathrm{Ar}) 7.69-7.73(\mathrm{~m}, 1 \mathrm{H}$, $\left.\mathrm{H}_{\text {quino }}\right), 7.80-7.82\left(\mathrm{~m}, 1 \mathrm{H}, \mathrm{H}_{\text {quino }}\right), 7.92-7.98\left(\mathrm{~m}, 2 \mathrm{H}, \mathrm{H}_{\text {quino }}\right), 8.96-9.00\left(\mathrm{~m}, 2 \mathrm{H}, \mathrm{H}_{\text {quino }}\right)$.

${ }^{13} \mathrm{C}-\mathrm{NMR}\left(101 \mathrm{MHz}, \mathrm{D}_{2} \mathrm{O}\right): \delta 36.84\left(\mathrm{CH}_{2}\right), 37.18(\mathrm{SCH}), 55.34\left(\mathrm{CH}_{3}\right), 61.78\left(\mathrm{CH}_{2} \mathrm{~N}\right)$, $112.80,114.59,121.35,121.70,125.61,126.51,127.91,129.14,130.46,132.69,133.07,143.36$, $146.56,148.55,148.68$.

Anal. Calcd for $\mathrm{C}_{19} \mathrm{H}_{18} \mathrm{NClO}_{2} \mathrm{~S}$ : C 63.41, H 5.04, N 3.89, Cl 9.85, S 8.91. Found: C 63.73, H5.21, N 4.01, Cl 10.31, S 9.29.

3-(4-Methoxyphenyl)-2-methyl-2H,3H-[1,4]thiazino[2,3,4-ij]quinolin-4-ium chloride (9). A solution of sulfuryl chloride $(0.103 \mathrm{~g}, 0.76 \mathrm{mmol})$ in methylene chloride $(10 \mathrm{~mL})$ was added dropwise to a solution of $\operatorname{di}(8$-quinolinyl $)$ disulfide $(0.243 \mathrm{~g}, 0.76 \mathrm{mmol})$ in methylene chloride $(10 \mathrm{~mL})$, and the mixture was stirred for $10 \mathrm{~min}$ at room temperature. A solution of trans-anethole $(0.226 \mathrm{~g}, 1.52 \mathrm{mmol})$ in methylene chloride $(10 \mathrm{~mL})$ was added dropwise, and the reaction mixture was stirred for $48 \mathrm{~h}$ at room temperature. The solvent was removed 
by rotary evaporator. The residue was dried in vacuum, giving the product $(0.523 \mathrm{~g}$, quantitative yield) in the form of a yellow powder, mp $97-100{ }^{\circ} \mathrm{C}$.

${ }^{1} \mathrm{H}-\mathrm{NMR}\left(400 \mathrm{MHz}, \mathrm{D}_{2} \mathrm{O}\right): \delta 1.43\left(\mathrm{~d}, \mathrm{~J}=7.0 \mathrm{~Hz}, 3 \mathrm{H}, \mathrm{CH}_{3}\right), 3.65\left(\mathrm{~s}, 3 \mathrm{H}, \mathrm{OCH}_{3}\right), 3.92(\mathrm{dd}$, $J=7.0,3.1 \mathrm{~Hz}, 1 \mathrm{H}, \mathrm{SCH}), 6.39(\mathrm{~d}, J=3.1 \mathrm{~Hz}, 1 \mathrm{H}, \mathrm{NCH}), 6.70(\mathrm{~d}, J=9.0 \mathrm{~Hz}, 2 \mathrm{H}, \mathrm{Ar}), 6.74(\mathrm{~d}$, $J=9.0 \mathrm{~Hz}, 2 \mathrm{H}, \mathrm{Ar}), 7.84-7.88\left(\mathrm{~m}, 1 \mathrm{H}, \mathrm{H}_{\text {quino }}\right), 7.93-7.95\left(\mathrm{~m}, 1 \mathrm{H}, \mathrm{H}_{\text {quino }}\right), 8.04-8.08(\mathrm{~m}, 1 \mathrm{H}$, $\left.\mathrm{H}_{\text {quino }}\right), 8.18-8.20\left(\mathrm{~m}, 1 \mathrm{H}, \mathrm{H}_{\text {quino }}\right), 9.15-9.16\left(\mathrm{~m}, 1 \mathrm{H}, \mathrm{H}_{\text {quino }}\right), 9.21-9.23\left(\mathrm{~m}, 1 \mathrm{H}, \mathrm{H}_{\text {quino }}\right)$.

${ }^{13} \mathrm{C}-\mathrm{NMR}\left(101 \mathrm{MHz}, \mathrm{D}_{2} \mathrm{O}\right): \delta 19.25\left(\mathrm{CH}_{3}\right), 38.18(\mathrm{SCH}), 55.23\left(\mathrm{OCH}_{3}\right), 74.33(\mathrm{NCH}), 114.17$, $122.18,124.12,126.68,127.75,129.65,130.30,131.09,133.18,134.52,150.10,150.25,159.10$.

Anal. Calcd for $\mathrm{C}_{19} \mathrm{H}_{18} \mathrm{NClOS}$ : C 66.36, $\mathrm{H}$ 5.28, N 4.07, $\mathrm{Cl} 10.31, \mathrm{~S} 9.33$. Found: C 66.46, H 5.34, N 4.15, Cl 10.84, S 9.91.

2-[(3,4-Dimethoxyphenyl)methyl]-2H,3H-[1,4]thiazino[2,3,4-ij]quinolin-4-ium chloride (10). A solution of sulfuryl chloride $(0.067 \mathrm{~g}, 0.50 \mathrm{mmol})$ in chloroform $(10 \mathrm{~mL})$ was added dropwise to a solution of di(8-quinolinyl) disulfide $(0.160 \mathrm{~g}, 0.50 \mathrm{mmol})$ in chloroform $(10 \mathrm{~mL})$, and the mixture was stirred for $10 \mathrm{~min}$ at room temperature. A solution of methyl eugenol $(0.178 \mathrm{~g}, 1.0 \mathrm{mmol})$ in chloroform $(10 \mathrm{~mL})$ was added dropwise, and the reaction mixture was stirred for $1 \mathrm{~h}$ at room temperature and $3 \mathrm{~h}$ at reflux temperature. The mixture was filtered, and the solvent was removed by rotary evaporator. The residue was washed with cold hexane and dried in vacuum, giving the product $(0.366 \mathrm{~g}, 98 \%$ yield $)$ in the form of a yellow powder, $\mathrm{mp} 179-180^{\circ} \mathrm{C}$.

${ }^{1} \mathrm{H}-\mathrm{NMR}\left(400 \mathrm{MHz}, \mathrm{D}_{2} \mathrm{O}\right): \delta 2.76-2.82\left(\mathrm{~m}, 1 \mathrm{H}, \mathrm{CH}_{2}\right), 2.93-2.98\left(\mathrm{~m}, 1 \mathrm{H}, \mathrm{CH}_{2}\right), 3.56(\mathrm{~s}$, $\left.3 \mathrm{H}, \mathrm{OCH}_{3}\right), 3.57\left(\mathrm{~s}, 3 \mathrm{H}, \mathrm{OCH}_{3}\right), 3.83-3.86(\mathrm{~m}, 1 \mathrm{H}, \mathrm{SCH}), 4.82-4.85\left(\mathrm{~m}, 1 \mathrm{H}, \mathrm{NCH}_{2}\right), 5.12-5.16$ (m, 1H, NCH $)_{2}$, 6.45-6.51 (m, 2H, Ar), 6.56 (s, 1H, Ar) 7.56-7.65 (m, 2H, H $\left.\mathrm{H}_{\text {quino }}\right), 7.80-7.82$ (m, 1H, $\left.\mathrm{H}_{\text {quino }}\right), 7.90-7.92\left(\mathrm{~m}, 1 \mathrm{H}, \mathrm{H}_{\text {quino }}\right), 8.89-8.94\left(\mathrm{~m}, 2 \mathrm{H}, \mathrm{H}_{\text {quino }}\right)$.

${ }^{13} \mathrm{C}-\mathrm{NMR}\left(101 \mathrm{MHz}, \mathrm{D}_{2} \mathrm{O}\right): \delta 37.20\left(\mathrm{CH}_{2}\right), 37.56(\mathrm{SCH}), 55.43\left(\mathrm{OCH}_{3}\right), 55.53\left(\mathrm{OCH}_{3}\right)$, $62.18\left(\mathrm{CH}_{2} \mathrm{~N}\right), 111.22,112.45,121.79,121.92,125.95,126.85,128.63,129.49,130.72,132.92$, 133.20, 146.92, 147.55, 148.92, 149.03.

Anal. Calcd for $\mathrm{C}_{20} \mathrm{H}_{20} \mathrm{NClO}_{2} \mathrm{~S}$ : C 64.25, H 5.39, N 3.75, Cl 9.48, S 8.58. Found: C 63.73, H 5.21, N 4.01, Cl 10.01, S 8.99.

\subsection{Synthesis of Compounds 11-14 from Styrene Derivatives and $1 H$-Indene}

3-Phenyl-2H,3H-[1,4]thiazino[2,3,4-ij]quinolin-4-ium chloride (11). A solution of sulfuryl chloride $(0.042 \mathrm{~g}, 0.31 \mathrm{mmol})$ in methylene chloride $(10 \mathrm{~mL})$ was added dropwise to a solution of di(8-quinolinyl) disulfide $(0.100 \mathrm{~g}, 0.31 \mathrm{mmol})$ in methylene chloride $(10 \mathrm{~mL})$, and the mixture was stirred for $10 \mathrm{~min}$ at room temperature. A solution of styrene $(0.065 \mathrm{~g}$, $0.62 \mathrm{mmol}$ ) in methylene chloride $(5 \mathrm{~mL})$ was added dropwise, and the reaction mixture was stirred for $24 \mathrm{~h}$ at room temperature. The mixture was filtered, and the solvent was removed by rotary evaporator. The residue was washed with cold hexane and dried in vacuum, giving the product $(0.18 \mathrm{~g}, 97 \%$ yield $)$ in the form of a light-yellow oil.

${ }^{1} \mathrm{H}-\mathrm{NMR}\left(400 \mathrm{MHz}, \mathrm{D}_{2} \mathrm{O}\right): \delta 3.78\left(\mathrm{dd}, J=14.3,3.5 \mathrm{~Hz}, 1 \mathrm{H}, \mathrm{SCH}_{2}\right), 3.98(\mathrm{dd}, J=14.3$, $\left.3.0 \mathrm{~Hz}, 1 \mathrm{H}, \mathrm{SCH}_{2}\right), 6.79-6.83(\mathrm{~m}, 1 \mathrm{H}, \mathrm{NCH}), 6.89-6.96$ (m, 2H, Ar), 7.36-7.44 (m, 3H, Ar), 7.91-7.95 (m, 1H, $\left.\mathrm{H}_{\text {quino }}\right), 8.08-8.13\left(\mathrm{~m}, 2 \mathrm{H}, \mathrm{H}_{\text {quino }}\right), 8.23-8.25\left(\mathrm{~m}, 1 \mathrm{H}, \mathrm{H}_{\text {quino }}\right), 9.21-9.27(\mathrm{~m}$, $\left.2 \mathrm{H}, \mathrm{H}_{\text {quino }}\right)$.

${ }^{13} \mathrm{C}-\mathrm{NMR}\left(101 \mathrm{MHz}, \mathrm{D}_{2} \mathrm{O}\right): \delta 29.77\left(\mathrm{SCH}_{2}\right), 69.32(\mathrm{NCH}), 121.99,125.76,126.34,128.05$, $129.14,129.23,129.32,129.45,133.91,134.12,136.95,149.62,150.31$.

Anal. Calcd for $\mathrm{C}_{17} \mathrm{H}_{14} \mathrm{ClNS}$ : C 68.10, $\mathrm{H} 4.71, \mathrm{Cl} 11.82, \mathrm{~N} 4.67, \mathrm{~S} 10.70$. Found: C 67.81, $\mathrm{H} 4.53, \mathrm{Cl} 12.01, \mathrm{~N} 4.48, \mathrm{~S} 10.48$.

$7 a H, 8 H, 12 b H$-Indeno[ $\left.1^{\prime}, 2^{\prime}: 5,6\right][1,4]$ thiazino[2,3,4-ij]quinolin-13-ium chloride (12). A solution of sulfuryl chloride $(0.071 \mathrm{~g}, 0.53 \mathrm{mmol})$ in methylene chloride $(10 \mathrm{~mL})$ was added dropwise to a solution of $\operatorname{di}(8$-quinolinyl $)$ disulfide $(0.169 \mathrm{~g}, 0.53 \mathrm{mmol})$ in methylene chloride $(10 \mathrm{~mL})$, and the mixture was stirred for $10 \mathrm{~min}$ at room temperature. A solution of $1 \mathrm{H}$-indene $(0.140 \mathrm{~g}, 1.06 \mathrm{mmol})$ in methylene chloride $(10 \mathrm{~mL})$ was added dropwise, and the reaction mixture was stirred for $65 \mathrm{~h}$ at room temperature. The mixture was filtered, and the solvent was removed by rotary evaporator. The residue was washed with cold 
hexane and dried in vacuum, giving the product $(0.266 \mathrm{~g}, 80 \%$ yield $)$ in the form of a yellow powder, $\mathrm{mp} 158-160^{\circ} \mathrm{C}$.

${ }^{1} \mathrm{H}-\mathrm{NMR}\left(400 \mathrm{MHz}, \mathrm{D}_{2} \mathrm{O}\right): \delta 3.07\left(\mathrm{~d}, J=16.8 \mathrm{~Hz}, 1 \mathrm{H}, \mathrm{CH}_{2}\right), 3.61(\mathrm{~d}, J=16.8 \mathrm{~Hz}, 1 \mathrm{H}$, $\left.\mathrm{CH}_{2}\right), 4.52(\mathrm{~d}, \mathrm{~J}=4.2 \mathrm{~Hz}, 1 \mathrm{H}, \mathrm{SCH}), 6.71(\mathrm{~s}, 1 \mathrm{H}, \mathrm{NCH}), 6.77-6.79(\mathrm{~m}, 1 \mathrm{H}, \mathrm{Ar}), 7.13-7.17$ (m, 1H, Ar), 7.33-7.36 (m, 1H, Ar), 7.45-7.46 (m, 1H, Ar), 7.68-7.72 (m, 1H, $\left.\mathrm{H}_{\text {quino }}\right), 7.81-7.83(\mathrm{~m}$, $\left.1 \mathrm{H}, \mathrm{H}_{\text {quino }}\right), 8.04-8.06\left(\mathrm{~m}, 1 \mathrm{H}, \mathrm{H}_{\text {quino }}\right), 8.19-8.22\left(\mathrm{~m}, 1 \mathrm{H}, \mathrm{H}_{\text {quino }}\right), 9.20-9.22\left(\mathrm{~m}, 1 \mathrm{H}, \mathrm{H}_{\text {quino }}\right)$, 9.43-9.44 (m, 1H, $\left.\mathrm{H}_{\text {quino }}\right)$.

${ }^{13} \mathrm{C}-\mathrm{NMR}\left(101 \mathrm{MHz}, \mathrm{D}_{2} \mathrm{O}\right): \delta 36.27\left(\mathrm{CH}_{2}\right), 39.61(\mathrm{SCH}), 72.47(\mathrm{NCH}), 121.6,122.27,125.14$, $126.38,127.22,127.33,129.12,129.49,131.04,132.50,138.22,138.68,138.71,149.35,149.81$.

Anal. Calcd for $\mathrm{C}_{18} \mathrm{H}_{14} \mathrm{NClS}$ : C 69.33, $\mathrm{H} 4.53, \mathrm{~N} 4.49, \mathrm{Cl} 11.37, \mathrm{~S} 10.28$. Found: C 69.46, $\mathrm{H} 4.68, \mathrm{~N} 4.63, \mathrm{Cl} 11.81, \mathrm{~S} 10.56$.

3-(4-Methylphenyl)-2H,3H-[1,4]thiazino[2,3,4-ij]quinolin-4-ium chloride (13). A solution of sulfuryl chloride $(0.097 \mathrm{~g}, 0.71 \mathrm{mmol})$ in methylene chloride $(10 \mathrm{~mL})$ was added dropwise to a solution of di(8-quinolinyl) disulfide $(0.230 \mathrm{~g}, 0.71 \mathrm{mmol})$ in methylene chloride $(10 \mathrm{~mL})$, and the mixture was stirred for $10 \mathrm{~min}$ at room temperature. A solution of 4-methylstyrene $(0.168 \mathrm{~g}, 1.42 \mathrm{mmol})$ in methylene chloride $(10 \mathrm{~mL})$ was added dropwise, and the reaction mixture wasstirred for $24 \mathrm{~h}$ at room temperature. The mixture was filtered, and the solvent was removed by rotary evaporator. The residue was dried in vacuum, giving the product (0.445 g, quantitative yield) in the form of a yellow powder, $\mathrm{mp} 73-75^{\circ} \mathrm{C}$.

${ }^{1} \mathrm{H}-\mathrm{NMR}\left(400 \mathrm{MHz}, \mathrm{D}_{2} \mathrm{O}\right): \delta 2.21\left(\mathrm{~s}, 3 \mathrm{H}, \mathrm{CH}_{3}\right), 3.67\left(\mathrm{dd}, J=14.2,3.2 \mathrm{~Hz}, 1 \mathrm{H}, \mathrm{SCH}_{2}\right)$, $3.89\left(\mathrm{dd}, J=14.2,2.4 \mathrm{~Hz}, 1 \mathrm{H}, \mathrm{SCH}_{2}\right), 6.72(\mathrm{~m}, 3 \mathrm{H}, \mathrm{NCH}, \mathrm{Ar}), 7.10(\mathrm{~d}, J=8.0 \mathrm{~Hz}, 2 \mathrm{H}, \mathrm{Ar})$, 7.84-7.88 (m, 1H, $\left.\mathrm{H}_{\text {quino }}\right)$, 7.98-8.00 (m, 1H, $\left.\mathrm{H}_{\text {quino }}\right), 8.04-8.08\left(\mathrm{~m}, 1 \mathrm{H}, \mathrm{H}_{\text {quino }}\right), 8.19-8.21$ (m, $\left.1 \mathrm{H}, \mathrm{H}_{\text {quino }}\right), 9.15-9.16\left(\mathrm{~m}, 1 \mathrm{H}, \mathrm{H}_{\text {quino }}\right), 9.22-9.24\left(\mathrm{~m}, 1 \mathrm{H}, \mathrm{H}_{\text {quino }}\right)$.

${ }^{13} \mathrm{C}-\mathrm{NMR}\left(101 \mathrm{MHz}, \mathrm{D}_{2} \mathrm{O}\right): \delta 20.11\left(\mathrm{CH}_{3}\right), 29.67\left(\mathrm{SCH}_{2}\right), 69.05(\mathrm{NCH}), 121.93,125.57$, 125.97, 127.93, 129.38, 129.41, 129.57, 131.37, 133.73, 133.90, 139.64, 149.48, 150.16.

Anal. Calcd for $\mathrm{C}_{18} \mathrm{H}_{16} \mathrm{NClS}$ : C 68.89, $\mathrm{H}$ 5.14, $\mathrm{N} 4.46, \mathrm{Cl} 11.30, \mathrm{~S} 10.22$. Found: C 69.00, H 5.21, N 4.54, Cl 11.56, S 10.68.

3-Methyl-3-phenyl-2H,3H-[1,4]thiazino[2,3,4-ij]quinolin-4-ium chloride (14). A solution of sulfuryl chloride $(0.108 \mathrm{~g}, 0.8 \mathrm{mmol})$ in methylene chloride $(10 \mathrm{~mL})$ was added dropwise to a solution of di(8-quinolinyl) disulfide $(0.256 \mathrm{~g}, 0.8 \mathrm{mmol})$ in methylene chloride $(10 \mathrm{~mL})$, and the mixture was stirred for $10 \mathrm{~min}$ at room temperature. A solution of $\alpha$-methylstyrene $(0.189 \mathrm{~g}, 1.6 \mathrm{mmol})$ in methylene chloride $(10 \mathrm{~mL})$ was added dropwise, and the reaction mixture was stirred for $24 \mathrm{~h}$ at room temperature. The mixture was filtered, and the solvent was removed by rotary evaporator. The residue was washed with cold hexane and dried in vacuum, giving the product $(0.436 \mathrm{~g}, 87 \%$ yield $)$ in the form of a yellow oil.

${ }^{1} \mathrm{H}-\mathrm{NMR}\left(400 \mathrm{MHz}, \mathrm{D}_{2} \mathrm{O}\right): \delta 1.58\left(\mathrm{~s}, 3 \mathrm{H}, \mathrm{CH}_{3}\right), 3.57\left(\mathrm{~d}, J=14.6,1 \mathrm{H}, \mathrm{SCH}_{2}\right), 3.78(\mathrm{~d}$, $\left.J=14.61 \mathrm{H}, \mathrm{SCH}_{2}\right), 6.58-6.64(\mathrm{~m}, 1 \mathrm{H}, \mathrm{Ar}), 6.66-6.72(\mathrm{~m}, 2 \mathrm{H}, \mathrm{Ar}), 7.00-7.05$ (m, 2H, Ar), 7.77-7.62 (m, 1H, $\left.\mathrm{H}_{\text {quino }}\right), 7.98-8.03\left(\mathrm{~m}, 1 \mathrm{H}, \mathrm{H}_{\text {quino }}\right), 8.07-8.13\left(\mathrm{~m}, 1 \mathrm{H}, \mathrm{H}_{\text {quino }}\right), 8.21-8.25(\mathrm{~m}$, $\left.1 \mathrm{H}, \mathrm{H}_{\text {quino }}\right), 8.90-8.94\left(\mathrm{~m}, 1 \mathrm{H}, \mathrm{H}_{\text {quino }}\right), 9.00-9.04\left(\mathrm{~m}, 1 \mathrm{H}, \mathrm{H}_{\text {quino }}\right)$.

${ }^{13} \mathrm{C}-\mathrm{NMR}\left(101 \mathrm{MHz}, \mathrm{D}_{2} \mathrm{O}\right): \delta 28.80\left(\mathrm{CH}_{3}\right), 50.91\left(\mathrm{SCH}_{2}\right), 74.85(\mathrm{NCH}), 122.00,124.79$, $126.84,127.22,127.86,129.28,129.41,130.14,136.99,141.46,143.67,144.20,148.31$.

Anal. Calcd for $\mathrm{C}_{18} \mathrm{H}_{16} \mathrm{NClS}$ : C 68.89, $\mathrm{H} 5.14, \mathrm{~N} 4.46, \mathrm{Cl} 11.30, \mathrm{~S} 10.22$. Found: C 69.12, $\mathrm{H} 4.99$, N 4.27, Cl 11.19, S 9.96.

\section{Conclusions}

A new family of water-soluble [1,4]thiazino[2,3,4-ij]quinolin-4-ium derivatives in 75-100\% yields have been developed based on the annulation reactions of 8-quinolinesulfenyl halides with natural products (eugenol, isoeugenol, methyl eugenol, trans-anethole) and alkenes (1-hexene, 1-heptene, styrene, 4-methylstyrene, $\alpha$-methylstyrene and $1 H$-indene).

The annulation reactions of 8-quinolinesulfenyl halides with styrene derivatives, which contain the double bond in conjugation with the benzene ring, and terminal alkenes including allyl arenes proceed in a regioselective fashion but with the opposite regiochemistry. The annulation reactions with styrene derivatives occur with the attachment of the sulfur atom of the 8-quinolinesulfenyl electrophile at the $\beta$-position of the vinyl 
group, whereas the opposite regiochemistry is observed in the case of terminal alkenes and allyl arenes.

The formation of possible intermediates in the annulation reactions of 8-quinolinesulfenyl halides with styrene derivatives and terminal alkenes including allyl arenes has been discussed. Three-membered thiiranium cations are assumed as intermediates in the reactions of 8-quinolinesulfenyl halides with terminal alkenes and allyl arenes. Nucleophilic attack of the nitrogen atom of the quinoline ring occurs at the unsubstituted carbon atom of thiiranium intermediates due to the steric factor. Linear carbocations are regarded as intermediates in the reactions with styrene derivatives. In this case, linear carbocations are energetically favorable due to their stabilization by the benzene ring.

Based on the evaluation of antimicrobial activity of novel water-soluble compounds against bacteria Enterococcus durans, Bacillus subtilis and Escherichia coli, the compounds with high activity have been found. A number of the obtained compounds are superior in their activity compared to the antibiotic gentamicin.

Supplementary Materials: The following are available online at https:/ / www.mdpi.com/article/10 $.3390 /$ app $11188532 / \mathrm{s} 1$, examples of ${ }^{1} \mathrm{H}$ - and ${ }^{13} \mathrm{C}$-NMR spectra of the obtained compounds.

Author Contributions: Conceptualization and the paper preparation, V.A.P.; methodology and research experiments, R.S.I.; antibacterial activity evaluation, L.A.B.; research experiments, I.V.S.; the data curation and supervision, S.V.A. All authors have read and agreed to the published version of the manuscript.

Funding: This research received no external funding.

Acknowledgments: The authors thank Baikal Analytical Center SB RAS for providing the instrumental equipment for structural investigations.

Conflicts of Interest: The authors declare no conflict of interest.

\section{References}

1. Matada, B.S.; Pattanashettar, R.; Yernale, N.G. A comprehensive review on the biological interest of quinoline and its derivatives. Bioorg. Med. Chem. 2021, 32, 115973. [CrossRef] [PubMed]

2. Nainwal, L.M.; Tasneem, S.; Akhtar, W.; Verma, G.; Khan, M.F.; Parvez, S.; Shaquiquzzaman, M.; Akhter, M.; Alam, M.M. Green recipes to quinoline: A review. Eur. J. Med. Chem. 2019, 164, 121-170. [CrossRef] [PubMed]

3. Chung, P.-Y.; Bian, Z.-X.; Pun, H.-Y.; Chan, D.; Chan, A.S.-C.; Chui, C.-H.; Tang, J.C.-O.; Lam, K.-H. Recent advances in research of natural and synthetic bioactive quinolines. Futur. Med. Chem. 2015, 7, 947-967. [CrossRef]

4. Weyesa, A.; Mulugeta, E. Recent advances in the synthesis of biologically and pharmaceutically active quinoline and its analogues: A review. RSC Adv. 2020, 10, 20784-20793. [CrossRef]

5. Kumar, S.; Bawa, S.; Gupta, H. Biological activities of quinoline derivatives. Mini Rev. Med. Chem. 2009, 9, 1648-1654. [CrossRef]

6. Raut, K.; Thombare, R.; Zagade, P.; Kumbhar, N. Different biological activities of quinoline. World J. Pharm. Res. 2020, 9, 674-689.

7. Abass, M.; Alzandi, A.R.A.; Hassan, M.M.; Mohamed, N. Recent advances on diversity oriented heterocycle synthesis of fused quinolines and its biological evaluation. Polycycl. Aromat. Compd. 2021, 1710856. [CrossRef]

8. Shiro, T.; Fukaya, T.; Tobe, M. The chemistry and biological activity of heterocycle-fused quinolinone derivatives: A review. Eur. J. Med. Chem. 2015, 97, 397-408. [CrossRef]

9. Jain, S.; Chandra, V.; Jain, P.K.; Pathak, K.; Pathak, D.; Vaidya, A. Comprehensive review on current developments of quinolinebased anticancer agents. Arab. J. Chem. 2019, 12, 4920-4946. [CrossRef]

10. Afzal, O.; Kumar, S.; Haider, R.; Ali, R.; Kumar, R.; Jaggi, M.; Bawa, S. A review on anticancer potential of bioactive heterocycle quinoline. Eur. J. Med. Chem. 2015, 97, 871-910. [CrossRef]

11. Shi, F.; Li, C.; Xia, M.; Miao, K.; Zhao, Y.; Tu, S.; Zheng, W.; Zhang, G.; Ma, N. Green chemoselective synthesis of thiazolo [3,2-a] pyridine derivatives and evaluation of their antioxidant and cytotoxic activities. Bioorganic Med. Chem. Lett. 2009, 19, 5565-5568. [CrossRef]

12. Manfroni, G.; Meschini, F.; Barreca, M.L.; Leyssen, P.; Samuele, A.; Iraci, N.; Sabatini, S.; Massari, S.; Maga, G.; Neyts, J.; et al. Pyridobenzothiazole derivatives as new chemotype targeting the HCV NS5B polymerase. Bioorganic Med. Chem. 2012, 20 , 866-876. [CrossRef]

13. Li, S.; Huang, Q.; Liu, Y.J.; Zhang, X.L.; Liu, S.; He, C.; Gong, P. Design, synthesis and antitumor activity of bisquinoline derivatives connected by 4-oxy-3-fluoroaniline moiety. Eur. J. Med. Chem. 2013, 64, 62-73. [CrossRef]

14. Panda, S.S.; Liaqat, S.; Girgis, A.; Samir, A.; Hall, C.D.; Katritzky, A.R. Novel antibacterial active quinolone-fluoroquinolone conjugates and 2D-QSAR studies. Bioorganic Med. Chem. Lett. 2015, 25, 3816-3821. [CrossRef] 
15. Feng, M.; Tang, B.; Liang, S.H.; Jiang, X. Sulfur containing scaffolds in drugs: Synthesis and application in medicinal chemistry. Curr. Top. Med. Chem. 2016, 16, 1200-1216. [CrossRef]

16. Good, J.A.D.; Kulen, A.M.; Almqvist, K.F.; Cairns, A.G.; Ponten, J.F. 2,3-Dihydrothiazolo [3,2-a] Pyridin-5-One Derivatives, Intermediates Thereof, and Their use as Antibacerial Agents. U.S. Patent 10,294,244, 21 May 2016.

17. Gao, C.; Fan, Y.-L.; Zhao, F.; Ren, Q.-C.; Wu, X.; Chang, L.; Gao, F. Quinolone derivatives and their activities against methicillinresistant Staphylococcus aureus (MRSA). Eur. J. Med. Chem. 2018, 157, 1081-1095. [CrossRef]

18. Hu, G.; Liang, J.; Liu, J.; Zhang, H. Preparation of propenone derivative of N-demethylated rufloxacin as antitumor drugs. Chem. Abstr. 2020, 173, 407358.

19. Cen, S.; Yang, L.; Li, X.; Hu, G. Preparation method of rufloxacin-containing bis-fluoroquinolone oxadiazole urea derivative applied to antitumor drug. Chem. Abstr. 2019, 171, 203187.

20. Fukuda, Y.; Seto, S.; Tanioka, A.; Ikeda, M. Preparation of pyridobenzothiazine derivatives having tachykinin antagonism, in particular, substance P receptor antagonism. Chem. Abstr. 2000, 132, 151827.

21. Hou, L.; Du, L.; Li, Y.; Hu, G.; Sun, J.; Zhang, C.; Shen, R.; Wang, N. Preparation of fluoroquinolone 1,3,4-thiadiazole urea rufloxacin derivatives useful for the treatment of cancer. Chem. Abstr. 2019, 171, 467857.

22. Lapointe, G.; Mergo, W.; Moser, H.E.; Rivkin, A.; Skepper, C.K.; Williams, S.L. Preparation of tricyclic 2-quinolinones as antibacterials. Chem. Abstr. 2018, 169, 515481.

23. Hu, G.; Wang, G.; Jing, Y. 3-[[2-(4-Pyridinylcarbonyl)hydrazinylidene]methyl]-7-fluoroquinolone derivatives useful in the treatment of tuberculosis. Chem. Abstr. 2012, 158, 131756.

24. Musalov, M.; Potapov, V.A. Selenium dihalides: New possibilities for the synthesis of selenium-containing heterocycles (microreview). Chem. Heterocycl. Compd. 2017, 53, 150-152. [CrossRef]

25. Musalov, M.V.; Yakimov, V.A.; Potapov, V.A.; Amosova, S.V.; Borodina, T.N.; Zinchenko, S.V. A novel methodology for the synthesis of condensed selenium heterocycles based on the annulation and annulation-methoxylation reactions of selenium dihalides. New J. Chem. 2019, 43, 18476-18483. [CrossRef]

26. Accurso, A.A.; Cho, S.-H.; Amin, A.; Potapov, V.A.; Amosova, S.V.; Finn, M.G. Thia-, Aza-, and Selena [3.3.1] bicyclononane dichlorides: Rates vs. internal nucleophile in anchimeric assistance. J. Org. Chem. 2011, 76, 4392-4395. [CrossRef] [PubMed]

27. Potapov, V.A.; Amosova, S.V.; Abramova, E.V.; Lyssenko, K.A.; Musalov, M.V.; Finn, M.G. Transannular addition of selenium dichloride and dibromide to 1,5-cyclooctadiene: Synthesis of 2,6-dihalo-9-selenabicyclo [3.3.1] nonanes and their complexes with selenium dihalides. New J. Chem. 2015, 39, 8055-8059. [CrossRef]

28. Potapov, V.; Amosova, S.; Kashik, A. Reactions of selenium and tellurium metals with phenylacetylene in three-phase catalytical systems. Tetrahedron Lett. 1989, 30, 613-616. [CrossRef]

29. Potapov, V.A.; Musalova, M.; Ishigeev, R.; Musalov, M.; Panov, V.A.; Khabibulina, A.G.; Amosova, S.V.; Bhasin, K.K. Efficient and selective syntheses of novel unsaturated chalcogen-containing pyridine derivatives. Tetrahedron Lett. 2016, 57, 5341-5343. [CrossRef]

30. Potapov, V.A.; Ishigeev, R.; Amosova, S.V.; Borodina, T.N. Synthesis of a novel family of water-soluble $2 H, 3 H-[1,3]$ thia- and -selenazolo[3,2-a]pyridin-4-ium heterocycles by annulation reactions. Tetrahedron Lett. 2019, 60, 475-479. [CrossRef]

31. Potapov, V.A.; Ishigeev, R.S.; Shkurchenko, I.V.; Zinchenko, S.V.; Amosova, S.V. Natural compounds and their structural analogs in regio- and stereoselective synthesis of new families of water-soluble $2 \mathrm{H}, 3 \mathrm{H}$-[1,3] thia- and -selenazolo[3,2- $a$ ]pyridin-4-ium Heterocycles by Annulation Reactions. Molecules 2020, 25, 376. [CrossRef]

32. Potapov, V.; Ishigeev, R.; Amosova, S. Efficient regioselective synthesis of novel water-soluble $2 H, 3 H$-[1,4] thiazino [2,3,4-ij] quinolin-4-ium derivatives by annulation reactions of 8-quinolinesulfenyl halides. Molecules 2021, 26, 1116. [CrossRef]

33. Ishigeev, R.S.; Potapov, V.A.; Skurchenko, I.V.; Khabibulina, A.G.; Amosova, S.V. Synthesis of new polycyclic compounds via the reaction of quinoline-8-sulfenyl halides with cyclic alkenes. Chem. Heterocycl. Comp. 2021, 57, 314-319. [CrossRef]

34. Kim, D.G.; Vershinina, E.A.; Sharutin, V.V. Synthesis, transformations and halocyclization of 8-(prop-2-ynylsulfanyl) quinoline and 8-(2-bromoprop-2-enylsulfanyl) quinoline. J. Sulfur. Chem. 2019, 41, 71-81. [CrossRef]

35. Kim, D.G. Halocyclization of 8-allylthioquinoline. Chem. Heterocycl. Compd. 1997, 33, 989-991. [CrossRef]

36. Batalov, V.I.; Kim, D.G.; Slepukhin, P.A. Heterocyclization of 8-(2-methyl-prop-2-enylsulfanyl) quinoline using electrophilic reagents. Chem. Heterocycl. Compd. 2013, 49, 1092-1096. [CrossRef]

37. Borisov, A.V.; Goncharova, T.V.; Borisova, G.N.; Osmanov, V.K.; Matsulevich, Z.V. Polar cycloaddition of 8-quinolinesulfenyl chloride to styrene. Chem. Heterocycl. Compd. 2001, 37, 382-383. [CrossRef]

38. Borisov, A.V.; Osmanov, V.K.; Borisova, G.N.; Matsulevich, Z.V.; Fukin, G.K. Synthesis of condensed sulfur- and nitrogencontaining heterocycles via polar cycloaddition of hetarene sulfenyl chlorides to a C-C multiple bond. Mendeleev Commun. 2009, 19, 49-51. [CrossRef]

39. Borisov, A.V.; Belsky, V.K.; Goncharova, T.V.; Borisova, G.N.; Osmanov, V.K.; Matsulevich, Z.V.; Frolova, N.G.; Savin, E.D. Sulfenyl halides in the synthesis of heterocycles. Part 2. Cyclization in reactions of hetarenesulfenyl chlorides with 3,3-dimethyl-1-butene. Chem. Heterocycl. Compd. 2006, 37, 771-777. [CrossRef]

40. Borisov, A.V.; Matsulevich, Z.V.; Osmanov, V.K.; Borisova, G.N.; Fukin, G.K.; Baranov, E. Unusual reaction of di(8-quinolyl) disulfide with norbornene. Chem. Heterocycl. Compd. 2010, 46, 1151-1153. [CrossRef]

41. Rasteikiene, L.; Greiciute, D.; Lin'Kova, M.G.; Knunyants, I.L. The addition of sulphenyl chlorides to unsaturated compounds. Russ. Chem. Rev. 1977, 46, 548-564. [CrossRef] 
42. Smit, V.A.; Zefirov, N.S.; Bodrikov, I.V.; Krimer, M.Z. Episulfonium ions: Myth and reality. Acc. Chem. Res. 1979, 12, $282-288$. [CrossRef]

43. Abu-yousef, I.A.; Harpp, D.N. New sulfenyl chloride chemistry: Synthesis, reactions and mechanisms toward carbon-carbon double bonds. Sulfur. Rep. 2003, 24, 255-282. [CrossRef]

44. Denmark, S.E.; Vogler, T. Synthesis and reactivity of enantiomerically enriched thiiranium ions. Chem. A Eur. J. 2009, 15, 11737-11745. [CrossRef]

45. Denmark, S.E.; Collins, W.R.; Cullen, M.D. Observation of direct sulfenium and selenenium group transfer from thiiranium and seleniranium ions to alkenes. J. Am. Chem. Soc. 2009, 131, 3490-3492. [CrossRef]

46. Soloshonok, V.A.; Nelson, D.J. Alkene selenenylation: A comprehensive analysis of relative reactivities, stereochemistry and asymmetric induction, and their comparisons with sulfenylation. Beilstein J. Org. Chem. 2011, 7, 744-758. [CrossRef]

47. Naredla, R.R.; Klumpp, D.A. Contemporary carbocation chemistry: Applications in organic synthesis. Chem. Rev. 2013, 113, 6905-6948. [CrossRef] [PubMed]

48. Mueller, W.H.; Butler, P.E. Orientational effects in the addition of acetylthiosulfenyl chloride to olefins. J. Org. Chem. 1967, 32, 2925-2929. [CrossRef]

49. Kharasch, N.; Potempa, S.J.; Wehrmeister, H.L. The sulfenic acids and their derivatives. Chem. Rev. 1946, 39, 269-332. [CrossRef] [PubMed]

50. Koval', I.V. S-Cationoid reagents in organic synthesis. Russ. Chem. Rev. 1995, 64, 141-166. [CrossRef]

51. Mueller, W.H.; Butler, P.E. Reaction of sulfenyl chlorides with allene. J. Org. Chem. 1968, 33, 1533-1537. [CrossRef]

52. Samuilov, Y.D.; Gainullin, V.I.; Solov'eva, S.E.; Konovalov, A.I. Reactivity of styrenes toward electrophilic addition of phenylsulfenyl chloride. Russ. J. Org. Chem. 1988, 24, 795-803. (In Russian)

53. Koval', I.V. Sulfenyl chlorides in organic synthesis. Russ. Chem. Rev. 1995, 64, 731-751. [CrossRef]

54. Olah, G.A. 100 years of carbocations and their significance in chemistry. J. Org. Chem. 2001, 66, 5943-5957. [CrossRef] [PubMed]

55. Wiegand, I.; Hilpert, K.; Hancock, R.E.W. Agar and broth dilution methods to determine the minimal inhibitory concentration (MIC) of antimicrobial substances. Nat. Protoc. 2008, 3, 163-175. [CrossRef] [PubMed] 